\title{
Analisis Perilaku Siswa SMP terhadap Kebijakan Kawasan Tanpa Rokok (KTR)
}

\author{
Dwi Hariyanti ${ }^{1}$, Mudita Sri Hidayah ${ }^{2}$, Chanif Kurnia Sari ${ }^{3}$ \\ 1-3Program Studi Kesehatan Masyarakat, Sekolah Tinggi Ilmu Kesehatan Surya Global, \\ Jl. Ringroad Selatan Potorono Banguntapan Bantul 55198 \\ E-mail: dwihariyanti@stikessuryaglobal.ac.id',muditasrih@yahoo.com², chanifks@gmail.com³
}

\begin{abstract}
Abstrak
Perokok pada remaja usia 10-I4 tahun semakin meningkat. Merokok akan berdampak pada perokok aktif dan juga lebih besar resikonya yaitu pada perokok pasif sehingga perlu dilakukan upaya pengamanan rokok bagi kesehatan, diantaranya melalui penetapan Kawasan Tanpa Rokok (KTR). Di Temanggung sebagai kota Tembakau belum memiliki perda yang mengatur tentang pelaksanaan kebijakan KTR. Penelitian ini bertujuan untuk mengetahui hubungan sikap, norma subjektif dan persepsi kontrol perilaku terhadap perilaku siswa terkait kebijakan terhadap KTR di SMP. Metode penelitian yang digunakan yaitu deskriptif kuantitatif dengan menggunakan pendekatan cross sectional. Populasi penelitian ini adalah siswa SMP Negeri di Temanggung kelas 8 dan 9. Pengambilan sampel menggunakan cluster sampling didapatkan 382 siswa. Analisis data bivariat yang digunakan yaitu Somers'd. Hasil analisis penelitian menunjukkan ada hubungan bermakna dengan tingkat hubungan yang lemah $(P v=0,006 ; r=0,246))$ antara sikap dengan perilaku siswa SMP terhadap kebijakan KTR dan tidak ada hubungan antara norma subyektif $(\mathrm{Pv}=0, \mathrm{I} 34)$ dan persepsi kontrol perilaku $(\mathrm{Pv}=0,088)$.

Kata Kunci: Kawasan Tanpa Rokok, kebijakan, perilaku, remaja SMP.
\end{abstract}

\begin{abstract}
Smoking behavior among adolescents age 10-1 4 years is increasing. Smoking not only affects active smokers, but a greater risk is that in passive smokers. Temanggung as a city of Tobacco do not yet have regulations governing the implementation of the policy of no-smoking area. In junior secondary schools in Temanggung there has been no dissemination about the policy of no-smoking area. So that the necessary studies related to the policy about no smoking area. This study aims to determine the relationship between attitudes, subjective norms and perceptions of behavioral control on student behavior related to policies on KTR in junior high schools. Methods a descriptive quantitative research with cross sectional approach. The population of this study were students of SMP Negeri in Temanggung grades 8 and 9, sampling technique using cluster sampling obtained 382 students. Analysis bivariat of the data used Somers'd. The results of the research analysis showed that there was a significant relationship with a weak level of relationship $(\mathrm{Pv}=0.006 ; r=0.246)$ ) between attitudes and behavior of junior high school students towards the no smoking area policy and there was no relationship between subjective norms $(P v=0.134)$ and perceptions of behavioral control $(P v=0.088)$.
\end{abstract}

Keywords: Non-Smoking Area, policy, behavior, junior high school students. 


\section{Pendahuluan}

Kebiasaan merokok di Indonesia meningkat, terutama pada anak dan remaja. Kondisi tersebut menunjukkan bahwa masalah merokok menjadi semakin serius, baik pada perokok aktif maupun orang yang ada di sekitarnya yang tidak merokok (perokok pasif). Oleh sebab itu perlu dilakukan langkah pengamanan rokok bagi kesehatan, salah satunya melalui penetapan Kawasan Tanpa Rokok (KTR). Diperkirakan lebih dari 40,3 juta anak yaitu tinggal bersama dengan perokok dan terpapar asap rokok dilingkungannya yang disebut sebagai perokok pasif, dampak yang ditimbulkan yaitu kerusakan kesehatan. Sekitar 40,3 juta anak umur 0-14 tahun terpapar asap rokok. ${ }^{1}$ Indonesia mengalami peningkatan perilaku merokok yang dimulai pada usia yang semakin muda. Pada usia 10-14 tahun, terdapat $2 \%$ remaja yang merokok dan $0,7 \%$ diantaranya merokok setiap hari dan $1,3 \%$ perokok kadang-kadang dengan rerata konsumsi 10 batang rokok per hari. ${ }^{2}$ Sekolah perlu dilibatkan secara intensif pada upaya pencegahan dan intervensi terhadap perilaku merokok pada anak dan rempaja. ${ }^{2}$

Penetapan KTR sangat perlu diselenggarakan yaitu di fasilitas pelayanan kesehatan, tempat proses belajar mengajar, tempat anak bermain, tempat ibadah, angkutan umum, tempat kerja, tempat umum dan tempat lain yang ditetapkan serta menjadi kewajiban asasi bagi kita semua terutama para pimpinan/penentu kebijakan di tempat tersebut dalam mewujudkannya. ${ }^{1}$ Indonesia sudah memiliki peraturan atau kebijakan tentang KTR atau kawasan bebas asap rokok yang tercantum dalam Peraturan Bersama Menteri Kesehatan dan Menteri Dalam Negeri No. 7 Tahun 2011 tentang Kawasan Tanpa Rokok dan pentingnya penyelenggaraan KTR pada fasilitas pelayanan kesehatan, tempat proses belajar mengajar, tempat anak bermain, tempat ibadah, angkutan umum, dan tempat lain yang ditetapkan untuk bisa melindungi masyarakat dari asap rokok. ${ }^{1}$ Penerapan kebijakan KTR atau Kawasan Dilarang
Merokok (KDM) bisa berpengaruh terhadap penurunan pada proporsi perokok setiap harinya. ${ }^{3}$

Presiden melalui Inpres No.1 tahun 2017 tentang gerakan masyarakat hidup sehat, menyampaikan kepada Kemenkes untuk melaksanakan kebijakan KTR dan Kemendikbud untuk mendorong sekolah sebagai Kawasan Tanpa Rokok serta kementrian lain. Pemerintah provinsi Jawa Tengah menetapkan peraturan Gubernur Jawa Tengah No 35 tahun 2017 tentang gerakan masyarakat hidup sehat di Jawa Tengah. Kabupaten Temanggung, belum memiliki peraturan tentang gerakan masyarakat hidup sehat. Sebagian besar mata pencaharian masyarakat Kabupaten Temanggung adalah petani dan paling banyak adalah pertanian tembakau sehingga Temanggung sering juga disebut kota Tembakau. Hal tersebut didukung oleh pernyataan Bupati Temanggung yang menyatakan bahwa "Masyarakat Temanggung jangan ada perayaan peringatan anti merokok, semua kawasan di Temanggung bebas untuk merokok kecuali pendidikan dan rumah sakit".

Penetapan KTR pada tempat belajar mengajar sudah diatur dalam Permendikbud No.64 Tahun 2015 tentang kawasan tanpa rokok di lingkungan sekolah. Beberapa sekolah menengah di Temanggung, dalam membuat peraturan larangan merokok di sekolah sudah mengacu pada peraturan tersebut. Hasil penelitian yang dilakukan oleh Schreuders et all menunjukkan bahwa, sekolah menengah yang menerapkan School Tobacco Police (STP) sangat dipengaruhi oleh implementasi yang memadai dan siklus pemantauan yang berkelanjutan mengenai respon kognitif dan perilaku siswa. ${ }^{4}$

Berdasarkan studi pendahuluan, penulis menggali informasi dari beberapa guru SMP di Temanggung terkait sosialisasi gerakan masyarakat hidup sehat terutama kebijakan tentang KTR yang belum pernah ada sosialisasi. Jumlah SMP di Temanggung sebanyak 76 SMP negeri dan swasta. Pada penelitian ini ada 4 SMP di daerah Temanggung yang tersebar pada daerah 
yang berbeda. Berdasarkan latar belakang dan studi pendahuluan, maka penelitian ini bertujuan untuk mengetahui hubungan sikap dan perilaku siswa terhadap penerapan KTR di SMP Temanggung.

\section{Metode}

Penelitian ini merupakan penelitian analisis kuantitatif observasional dengan menggunakan pendekatan cross sectional. ${ }^{5}$ Peneliti menggunakan teknik pengambilan sampel cluster sampling dan didapatkan 4 SMP Negeri yaitu SMPN 6 Temanggung sebanyak 54 siswa, SMPN 2 Tlogomulyo sebanyak 12 siswa, SMPN 2 Ngadirejo sebanyak 264 siswa dan SMPN 1 Gemawang sebanyak 52 siswa. Sampel yang diambil dalam penelitian ini yaitu siswa kelas VII dan kelas IX, dengan kriteria inkusi sehat jasmani dan rohani, memiliki gadget, bisa online saat penelitian dilakukan. Sedangkan kriteria eksklusi yaitu siswa yang tidak bisa mengikuti pengambilan data secara online. Jumlah sampel secara keseluruhan yang diambil dari 4 SMP tersebut yaitu 382 sampel. Pengumpulan data tentang sikap, norma subyektif, persepsi kontrol perilaku dan perilaku tentang kebijakan KTR menggunakan kuesioner online dengan google form. Sebelum kuesioner dibagikan untuk pengambil data, dilakukan uji validitas menggunakan analisis product moment dan uji reliabilitas menggunakan uji Alfa Cronbach. Analisis bivariat untuk mengetahui korelasi/hubungan antara sikap, norma subyektif, persepsi kontrol perilaku dengan perilaku menggunakan analisis Somers'd. ${ }^{6}$ Uji Somer's digunakan, untuk menguji adakah hubungan pada variabel bebas dengan variabel terikat yang dapat dilihat dari value dan approx $\operatorname{sig}<0,05$.

\section{Hasil}

Gambaran secara umum tentang karakteristik responden pada penelitian ini yaitu meliputi usia, jenis kelamin, mata pencaharian orangtua dan status merokok.
Tabel 1. Distribusi Frekuensi Berdasarkan Karakteristik Siswa di SMPN Temanggung

\begin{tabular}{llcc}
\hline \multicolumn{1}{c}{ Variabel } & \multicolumn{1}{c}{ Kategori } & n & \% \\
\hline Usia & $\leq 15$ tahun & 363 & 95,0 \\
& $>15$ tahun & 18 & 4,7 \\
Jenis kelamin & Laki-laki & 162 & 42,4 \\
& Perempuan & 220 & 57,6 \\
Mata & Pertanian kopi & 40 & 10,5 \\
pencaharian & Petanian Padi & 28 & 7,3 \\
orangtua & Petanian sayur & 76 & 19,9 \\
& Pertanian tembakau & 92 & 24,1 \\
& Bangunan & 1 & 0,3 \\
& Lainnya & 125 & 37,0 \\
Status & Merokok & 56 & 14,7 \\
& Tidak merokok & 326 & 85,3 \\
\hline
\end{tabular}

Berdasarkan tabel 1 terlihat bahwa karakteristik usia responden sebagian besar pada kelompok usia $\leq 15$ tahun, yaitu sebanyak 363 responden (95\%). Responden terbanyak berjenis kelamin perempuan yaitu 220 responden (57,6\%). Karakteristik berdasarkan mata pencaharian orang tua paling banyak yaitu lainnya sejumlah 125 responden $(37 \%)$ dan yang terbanyak kedua yaitu pada mata pencaharian sebagai petani tembakaku sebanyak 92 responden $(24,1 \%)$. Sebagian besar responden tidak merokok yaitu 326 responden $(85,3 \%)$.

Tabel 2. Distribusi Frekuensi Variabel Penelitian

\begin{tabular}{llcc}
\hline Variabel & Kategori & n & \% \\
\hline Sikap & Kurang baik & 35 & 9,2 \\
& Cukup baik & 284 & 74,3 \\
& Baik & 63 & 16,5 \\
Norma & Kurang baik & 2 & 5,0 \\
Subyektif & Cukup baik & 96 & 25,1 \\
& Baik & 284 & 74,3 \\
Persepsi kontrol & Kurang baik & 64 & 16,8 \\
perilaku & Cukup baik & 210 & 55,0 \\
& Baik & 108 & 28,3 \\
Perilaku & Kurang baik & 7 & 1,8 \\
& Cukup baik & 25 & 6,5 \\
& Baik & 350 & 91,6 \\
\hline
\end{tabular}

Berdasarkan tabel 2 dapat disampaikan bahwa sebagian besar responden mempunyai sikap yang cukup baik sebanyak 284 responden (74,3\%). Norma subyektif sebagian besar pada 
kategori baik sejumlah 284 responden $(74,35)$. Variabel persepsi kontrol perilaku, paling tinggi yaitu pada kategori cukup baik sejumlah 210 responden $(55,0 \%)$. Sebagian besar responden memiliki perilaku yang baik yaitu 350 responden $(91,6 \%)$.

Tabel 3. Analisis Bivariat

\begin{tabular}{|c|c|c|c|c|c|c|c|c|c|}
\hline \multirow{3}{*}{ Variabel } & \multirow{3}{*}{ Kategori } & \multicolumn{6}{|c|}{ Perilaku terhadap KTR } & \multirow{3}{*}{$\mathbf{P v}$} & \multirow{3}{*}{$\begin{array}{c}\text { Nilai } \\
\text { Somers'd }\end{array}$} \\
\hline & & \multicolumn{2}{|c|}{ Kurang Baik } & \multicolumn{2}{|c|}{ Cukup Baik } & \multicolumn{2}{|c|}{ Baik } & & \\
\hline & & $\mathbf{n}$ & $\%$ & $\mathbf{n}$ & $\%$ & $\mathbf{n}$ & $\%$ & & \\
\hline \multirow[t]{3}{*}{ Sikap } & Kurang baik & 3 & 8,6 & 5 & 14,3 & 27 & 77,1 & 0,246 & 0,006 \\
\hline & Cukup baik & 4 & 1,4 & 18 & 6,3 & 262 & 92,3 & & \\
\hline & Baik & 0 & 0 & 2 & 3,2 & 61 & 96,8 & & \\
\hline \multirow[t]{3}{*}{ Norma Subyektif } & Kurang baik & 1 & 50 & 0 & 0 & 1 & 50 & 0,138 & 0,134 \\
\hline & Cukup baik & 3 & 3,1 & 8 & 8,4 & 85 & 88,5 & & \\
\hline & Baik & 3 & 1,1 & 17 & 6 & 264 & 92,9 & & \\
\hline \multirow{3}{*}{$\begin{array}{l}\text { Persepsi kontrol } \\
\text { perilaku }\end{array}$} & Kurang baik & 3 & 4,7 & 9 & 14,1 & 52 & 81,2 & 0,191 & 0,088 \\
\hline & Cukup baik & 3 & 1,4 & 9 & 4,3 & 198 & 94,3 & & \\
\hline & Baik & 1 & 0,9 & 7 & 6,5 & 100 & 92,6 & & \\
\hline
\end{tabular}

Pada tabel 3 memperlihatkan nilai korelasi pada variabel bebas dengan variabel terikat. Korelasi antara variabel sikap dengan perilaku menunjukkan ada hubungan yang bermakna yaitu dengan nilai $\mathrm{Pv}=0,006$ dan pada nilai Somers'd didapatkan nilai korelasinya 0,246 yaitu hubungan pada kategori lemah. Nilai tertinggi pada tabulasi silang sikap dengan perilaku yaitu sikap pada kategori cukup baik memiliki perilaku yang baik sebanyak 262 responden. Tidak ada responden yang sikapnya baik dan perilakunya kurang baik.

Hubungan antara variabel norma subyektif dengan perilaku ditunjukkan pada tabel tersebut terlihat bahwa antara kedua variabel tidak ada hubungan yang bermakna $(0,134)$. Dapat dilihat pada tabel bahwa norma subyektif yang baik dan perilakunya baik ada sebanyak 264 responden, dan hanya ada 1 responden yang norma subyektifnya kurang baik dan perilakunya baik. Pada variabel persepsi kontrol perilaku dengan perilaku kebijakan kawasan tanpa rokok yaitu tidak ada hubungan yang signifikan.

\section{Pembahasan}

Pengujian hubungan dengan menggunakan uji Somers'd, didapatkan hasil ada hubungan bermakna antara sikap dengan perilaku terhadap kebijakan Kawasan Tanpa Rokok. Tidak ada responden yang sikapnya baik dan perilakunya kurang baik. Hasil analisis pada penelitian ini, sesuai dengan pendapat yang dikemukakan oleh Surahman bahwa sikap merupakan kesiapan atau kesediaan untuk bertindak atau predisposisi tindakan. ${ }^{7}$ Terlihat dalam tabulasi silang bahwa sebagian besar responden yang sikapnya cukup baik maka perilakunya baik. Ketika seseorang bertindak/berperilaku terkait kebijakan kawasan tanpa rokok, maka sebenarnya orang tersebut telah memiliki kesiapan untuk melaksanakannya. Seperti penelitian yang telah dilakukan oleh Maradesa, dkk yang menyebutkan bahwa ada hubungan sikap dengan tindakan/perilaku tentang kebijakan Kawasan Tanpa Rokok. ${ }^{8}$ Hasil penelitian ini mendukung penelitian yang telah dilakukan oleh Hutapea yang menunjukkan adanya hubungan antara sikap dengan tindakan terhadap kebijakan kawasan tanpa rokok. ${ }^{9}$ Penelitian Sualang, dkk juga menyimpulkan bahwa terdapat korelasi yang bermakna antara sikap dengan perilaku. ${ }^{10}$ Seperti yang disampaikan oleh Lestari dan Merek, bahwa sikap yang baik akan membentuk perilaku yang baik pula. ${ }^{11,12}$

Korelasi variabel norma subyektif dan variabel perilaku dengan menggunakan uji Somers'd, mendapatkan hasil yang tidak bermakna atau tidak ada korelasi. Seperti pendapat yang dikemukakan oleh Ajzen 
bahwa norma subyektif adalah perasaan seseorang terhadap harapan dari orang yang ada dalam kehidupannya terkait hal dilakukan atau tidak dilakukannya perilaku, jika dalam penelitian ini yaitu bahwa norma subyektif tersebut tidak ada hubungannya dengan perilaku seseorang terhadap kebijakan kawasan tanpa rokok. ${ }^{13,14} \mathrm{Di}$ tempat penelitian, pengelola sekolah sudah memiliki peraturan tentang kawasan tanpa rokok yang merujuk pada Permendikbud RI No. 64 Tahun 2015. Pihak pengelola sekolah juga sudah menempel pesan tentang kawasan tanpa rokok. Pemerintah pada tingkat kabupaten belum memiliki peraturan yang bisa di laksanakan oleh masyarakat terkait kebijakan kawasan tanpa rokok.

Korelasi variabel persepsi kontrol perilaku dengan variabel perilaku, diuji dengan menggunakan analisis Somers'd dan menunjukkan tidak ada korelasi antara persepsi kontrol perilaku dengan perilaku terkait kebijakan kawasan tanpa rokok. Melihat hasil analisa tersebut jika dikaji dengan pendapat yang disampaikan Ajzen bahwa persepsi kontrol perilaku merupakan perasaan seseorang mengenai mudah atau sulitnya mewujudkan suatu perilaku tertentu. ${ }^{15}$ Pada hasil penelitian ini perilaku responden pada kategori baik itu tidak ada hubungan yang bermakna dengan perilaku yang baik terhadap kebijakan kawasan tanpa rokok. Sekolah belum menyiapkan infrastruktur yang memadai untuk mendukung perilaku terhadap kebijakan kawasan tanpa rokok, sehingga menjadi agak sulit bagi warga sekolah untuk menerapkan kebijakan KTR. Infrastruktur tersebut meliputi membuat surat keputusan dari pimpinan yaitu tentang penanggungjawab dan pengawas KTR, instrumen untuk pengawasan, materi sosialisasi terkait penerapan KTR, pembuatan dan penempatan tanda larangan merokok, mekanisme dan saluran pesan tentang KTR, pelatihan bagi pengawas KTR dan pelatihan kelompok sebaya bagi karyawan/guru/siswa tentang cara berhenti merokok. ${ }^{1}$

\section{Kesimpulan}

Dari hasil penelitian ini dapat disimpulkan bahwa sikap memiliki hubungan dengan perilaku tentang kebijakan Kawasan Tanpa Rokok sedangkan norma subyektif dan persepsi kontrol perilaku tidak berhubungan. Pihak sekolah bisa menyediakan informasi maupun sumberdaya (peralatan, kompatibilitas, kompetensi dan kesempatan) bagi siswa maupun guru/pegawai untuk mendukung kebijakan kawasan tanpa rokok disekolah. Peneliti selanjutnya bisa menambahkan dan/atau meneliti variabel lain yang belum diteliti pada penelitian ini. Selanjutnya melakukan penelitian yang lebih mendalam mengenai Theory of Plann Behavior terhadap perilaku kesehatan.

\section{Ucapan Terima Kasih}

Ucapan terimakasih peneliti sampaikan kepada Guru di SMP tempat penelitian dilakukan atas dukungannya, sampai peneliti selesai melakukan penelitian.

\section{Daftar Pustaka}

1. Kemenkes RI. Pedoman Pengembangan Kawasan Tanpa Rokok. Jakarta: Pusat Promosi Kesehatan; 2011.

2. Rachmat M, Thaha RM, Syafar M. Smoking Behavior at Junior High School. J Kesehat Masy Nas. 2013;7:502-8.

3. Rahajeng. Pengaruh Penerapan Kawasan Tanpa Rokok Terhdap Penurunan Proporsi Perokok di Provinsi DKI Jakarta DIY dan Bali. J Ekol Kesehat. 2015;14:238-49.

4. Michael Schreuders, A.W.Nuyts, Paulien, Putte, Den B, E.Kunst, et al. Understanding the impact of school tobacco policies on adolescent smoking behaviour: A realist review. Soc Sci Med [Internet]. 2017;183:19-27. Available from:

https://www.sciencedirect.com/science/article/a bs/pii/S0277953617302629

5. Suharsimi A. Prosedur Penelitian Suatu Pendekatan Praktik. Jakarta: Rineka Cipta; 2013.

6. Dahlan MS. Statistik untuk Kedokteran dan Kesehatan. Jakarta: Salemba Medika; 2013.

7. Surahman S. Ilmu Kesehatan Masyarakat PKM. Jakarta: Kemenkes RI; 2016.

8. Maradesa AY, Rumayar AA, Kandou GD. Hubungan antara Pengetahuan dan Sikap dengan Tindakan tentang Kebijakan Kawasan 
Tanpa Rokok pada Pelajar di SMP Negeri 1 Manado. 2019;1(2):34-9.

9. Hutapea. C.E.Z, Rumayar.AA MF. Hubungan antara pengetahuan dan sikap dengan tindakan terhadap kebijakan kawasan tanpa rokok pada siswa di SMP Kristen Tateli. Fak Kesehat Masy Univ Sam Ratulangi. 2017;1-13.

10. Sualang JS, Rumayar AA, Tucunan AAT, Kesehatan F, Universitas M, Ratulangi S. Hubungan antara Pengetahuan dan Sikap dengan Tindakan terhadap Kebijakan Kawasana Tanpa Rokok pada Pelajar di SMA Negeri 7 Manado. J Kesmas. 2019;8(2):7-14.

11. Lestari W. Sikap Mahasiswa Universitas Gunadarma Tentang Kawasan Tanpa Rokok Dengan Perilaku Merokok. Inform Kedokt J Ilm [Internet]. 2019;2(1):47-53. Available from:

https://ejournal.gunadarma.ac.id/index.php/me dif/article/view/2296

12. Merek IA, Supriyatni N. Pengetahuan, Sikap dan Tindakan Masyarakat Terhadap Implementasi Kawasan Tanpa Rokok di Taman
Nukila , Fort Oranje dan Landmark Kota Ternate. J Biosainstek [Internet]. 2020;2(36):6-11. Available from: http://jurnal.ummu.ac.id/index.php/BIOSAINS TEK/article/view/466/313

13. Fishbein M, Ajzen I. The Influence of Attitudes on Behavior. Handb Attitudes [Internet]. 2005;(July):173-222. Available from: http://books.google.com/books?hl=en\&lr=\&id $=$ qoJ5AgAAQBAJ\&oi=fnd $\& p g=P A 173 \& d q=T$ he+Influence+of+Attitudes+on+Behavior\&ots =I3vmnYWDce\&sig=1ASAmi1gqxpMyNlnszy UROK82Fg\%0Ahttp://books.google.com/book $\mathrm{s}$ ?hl=en\&lr=\&id=qoJ5AgAAQBAJ\&oi=fnd \&p $\mathrm{g}=\mathrm{PA} 173 \& \mathrm{dq}=$ The+influence + of +

14. Mahyarni. Theory of Reasoned Action Dan Theory of Planned Behavior (Sebuah Kajian Historis tentang Perilaku). J El Riyasah. 2013;4(1):13-23.

15. Ajzen I. The theory of planned behavior. Organ Behav Hum Decis Process. 1991;50(2):179-211. 